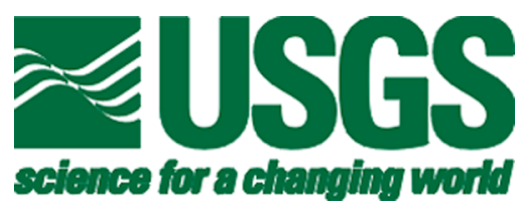

U.S. GEOLOGICAL SURVEY EASTERN REGION NORTHEAST FOCUS AREA

\title{
COASTAL ECOSYSTEMS AND RESOURCES FRAMEWORK FOR SCIENCE
}

By John Bratton, Glenn Guntenspergen, Bruce Taggart, Douglas Wheeler, Lynn Bjorklund, Michael Bothner, Rama Kotra, Robert Lent, Ellen Mecray, Hilary Neckles, Barbara Poore, Stephen Rideout, Susan Russell-Robinson, and Peter Weiskel

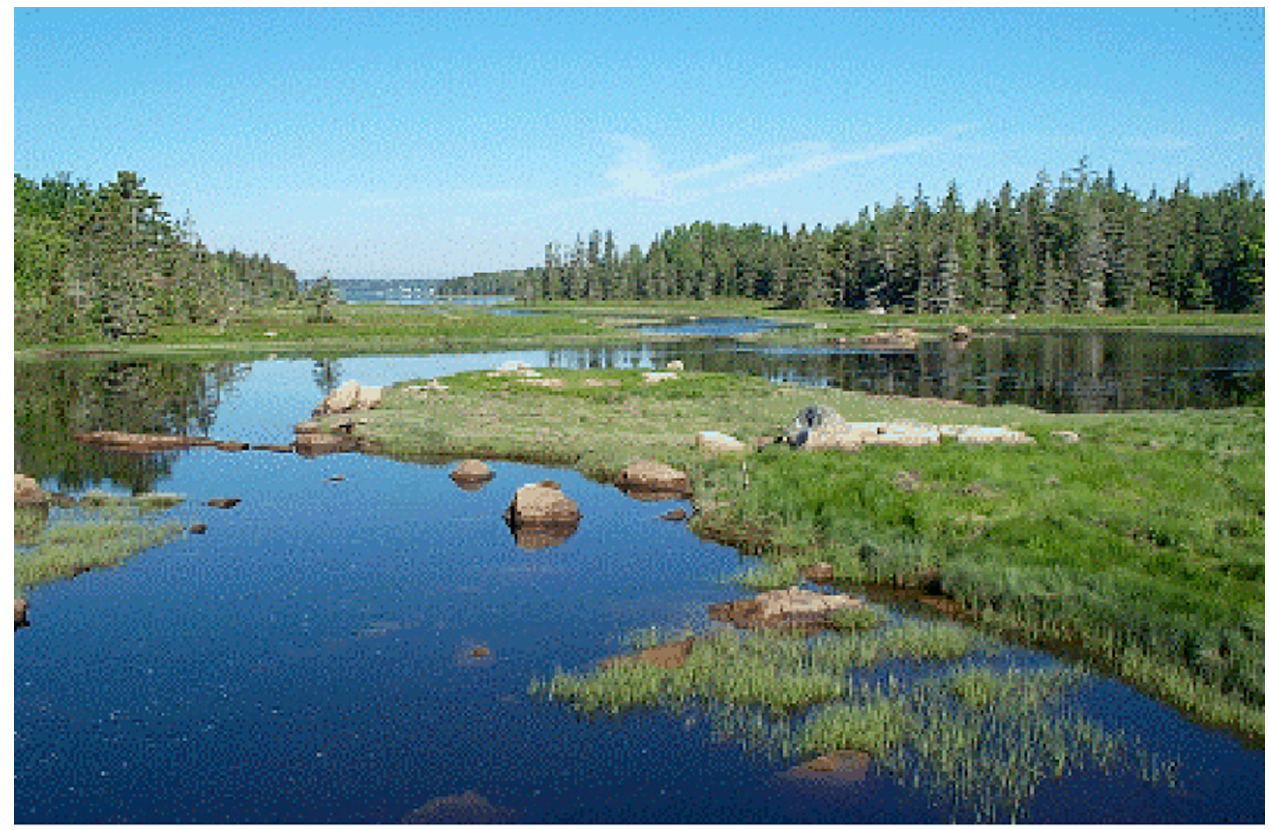

U.S. GEOLOGICAL SURVEY OPEN-FILE REPORT OF-03-405 


\title{
CONTENTS
}

\author{
Executive Summary 1 \\ Acknowledgments $\mathbf{2}$ \\ Introduction $\mathbf{2}$ \\ Geographic Setting of the Northeast Coastal Ecosystems and Resource Focus Area 4 \\ USGS Role in Integrated Science in the Northeast $\mathbf{4}$ \\ Prioritizing Integrated Science Issues in the Northeast $\mathbf{4}$ \\ Rationale for Integrated Science Themes $\mathbf{5}$ \\ Fluxes of Water, Nutrients, Sediment, and Contaminants $\mathbf{5}$ \\ Coastal Hazards $\mathbf{6}$ \\ Urbanization and Habitat Change $\mathbf{6}$ \\ Long-Term Scientific Issues $\mathbf{6}$ \\ Fluxes of Water, Nutrients, Sediment, and Contaminants $\mathbf{6}$ \\ Coastal Hazards $\mathbf{8}$ \\ Urbanization and Habitat Change 9 \\ Geographic Focus Areas for Integrated Sciences $\mathbf{1 1}$ \\ Gulf of Maine $\mathbf{1 1}$ \\ Acadia National Park, Maine 11 \\ Great Bay/Piscatauqua River Estuary $\mathbf{1 1}$ \\ Merrimack River, Estuary, and Adjacent Salt Marsh Systems \\ 12 \\ Massachusetts Bay $\mathbf{1 2}$ \\ Boston Metropolitan Area: Charles River/ \\ Boston Harbor/Massachusetts Bay $\mathbf{1 2}$ \\ Cape Cod 13 \\ Southern New England 13 \\ Narragansett Bay 13 \\ Southern New England Coastal Ponds $\mathbf{1 4}$ \\ Coastal Department of Defense Facilities 14 \\ Connecticut River/Long Island $\mathbf{1 4}$ \\ Action Plan Recommendations $\mathbf{1 5}$ \\ Science 15 \\ Fluxes 15 \\ Hazards $\mathbf{1 6}$ \\ Management and Communications $\mathbf{1 6}$ \\ Internal Science Management and Planning $\mathbf{1 6}$ \\ Internal Science Information Exchange and Collaboration $\mathbf{1 6}$ \\ External Relationships and Communications $\mathbf{1 7}$ \\ Selected References $\mathbf{1 8}$
}

\section{FIGURES}

Map showing Northeast coastal area $\mathbf{3}$

Schematic diagram showing important natural processes and human pressures that affect coastal ecosystems and resources of the Northeast 
Wetlands habitat $\mathbf{8}$

Graph showing incidence of Lyme disease, 1994-1996 $\mathbf{1 0}$

Map showing 1990 Cape Cod land cover $\mathbf{1 3}$

Connecticut River Valley

15

\section{APPENDIXES}

1. Northeast Coastal Long-Term Integrated Science Priorities and Partners, Cooperators, and Stakeholders 19

2. Northeast Coastal Long-Term Integrated Science Priorities and Bureau Programs 20

3. Northeast Coastal Long-Term Integrated Science Priorities and Bureau Integrated Science Themes $\mathbf{2 1}$

4. Northeast Coastal Long-Term Integrated Science Priorities and Eastern Region Integrated Science Priorities 22 


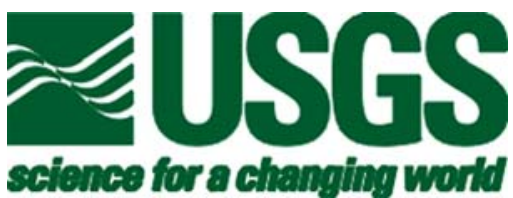

\title{
U.S. GEOLOGICAL SURVEY OPEN-FILE REPORT OF-03-405
}

\author{
U.S. GEOLOGICAL SURVEY EASTERN REGION \\ NORTHEAST FOCUS AREA
}

\section{COASTAL ECOSYSTEMS AND RESOURCES FRAMEWORK FOR SCIENCE}

\author{
By John Bratton, Glenn Guntenspergen, Bruce Taggart, Douglas Wheeler, Lynn Bjorklund, \\ Michael Bothner, Rama Kotra, Robert Lent, Ellen Mecray, Hilary Neckles, Barbara Poore, \\ Stephen Rideout, Susan Russell-Robinson, and Peter Weiskel
}

\section{EXECUTIVE SUMMARY}

The fragile coastal areas of the Northeast, stretching from Long Island Sound to Maine, are threatened by a host of manmade and natural stressors. The issues involving coastal ecosystems and resources in the Northeastern United States stem from complex interactions across a variety of temporal and spatial scales. These issues can be addressed only by integrated, multidisciplinary, and interdisciplinary science. Responding to stakeholder needs, and building on a long history of scientific excellence, the Eastern Region of U.S. Geological Survey (USGS) offers this plan for integrated science to guide future activities and to expand existing partnerships with other Federal, state, and local governments, universities, non-governmental organizations, and private-sector business in the region.

The plan was formulated following a meeting convened by the USGS in January 2003 at the Coastal Institute of the University of Rhode Island at Narragansett, R.I. More than 70 scientists from the four USGS disciplines -Water, Geology, Biology, and Geography -- met with representatives of over a dozen partner organizations. Meeting participants prioritized key issues associated with major threats in the coastal zone, identified a number of geographic areas where interdisciplinary efforts could be expanded, and recommended specific actions to increase interdisciplinary science and engage cooperators. A writing team distilled the meeting discussions into this integrated science plan meant to capitalize on the strength of the USGS disciplines and to identify expertise needed from outside collaborators.

The themes identified as the most significant long-term science issues for which the USGS has both mandates and the expertise to address were:

- Fluxes of Water, Nutrients, Sediment, and Contaminants

- Coastal Hazards

- Urbanization and Habitat Change

Workshop participants identified the following areas as likely sites in which to focus short-term integrated science efforts:

- Acadia National Park, Maine

- Great Bay/Piscataqua River Estuary

- Merrimack River and adjacent estuary-salt marsh systems

- Boston Metropolitan Area: Charles River/Boston Harbor/Massachusetts Bay

- Cape Cod

- Narragansett Bay

- Southern New England Coastal Ponds 
- Coastal Department of Defense Facilities

- Connecticut River/Long Island Sound.

This plan recommends a suite of actions focused on the three themes. Highlights of these recommendations include:

- Increasing our understanding of the movement of chemical and biological agents and sediment through coastal ecosystems and their effects on biota and water quality

- Using emerging technologies such as LIDAR and merged topographic/ bathymetric data sets and new modeling and visualization tools to develop vulnerability assessments for coastal areas and to predict shoreline change, sea level rise, and the loss of wetlands

- Developing a better understanding of the links between past, current and future landuse practices and water, sediment concentrations, and biological communities to better predict the impacts of coastal urbanization and sprawl

- Leveraging long-term databases and monitoring to develop scientific information and new decision support tools to guide restoration efforts in the coastal zone.

In addition, the plan includes a section on management and communications priorities for the Northeast Focus Area of the Eastern Region. The New England Discipline Mangers Advisory Committee will develop a strategy for implementing the recommendations in this science plan through leveraging activities already underway and engaging key partners and cooperators.

\section{Acknowledgements}

The Steering Committee offers its sincere thanks for the support, guidance, and leadership given to this project by Bonnie McGregor, Regional Director for the Eastern Region, and David Russ, Regional Executive for eastern Regional Geology. We welcome their continued interest in USGS integrated science in New England.
Special thanks to Peter August, Director, University of Rhode Island Coastal Institute, for hosting the workshop session, providing student support to record session notes, and funding the Estuaries Cabaret. Thanks also to workshop speakers John W. Farrington, Vice President of Academic Programs, and Dean, Woods Hole Oceanographic Institution; Arthur Lerner-Lam, Director, Center for Hazards and Risk Research, Lamont-Doherty Earth Observatory, Columbia University; and Scott W. Nixon, Professor of Oceanography at the University of Rhode Island. University of Rhode Island students Q. Kellogg, Emily Wild, Jacqui Steinbeck, Kelly Stroker, Marina Yasvoins, and Andy Wezniak ably served as meeting recorders. Many thanks to meeting facilitators Brad Barr, Denis LeBlanc, Hilary Neckles, Andrew Raddant, Susan Russell-Robinson, and Jeff Williams and to others who helped with workshop support, including Robert Ayuso, James Campbell. Susan Hellman, Wright Horton, Howie Ginsberg, and Marilyn Bucholtz Ten-Brink. A special thanks goes to Judith Swift and members of the Estuaries Cabaret, who provided timely and amusing entertainment for the meeting. Finally, the workshop would not have been possible without the leadership of Susan Warner of The LEAD Alliance, who guided the steering committee from inception through the preparation of this report.

\section{INTRODUCTION}

The fragile coastal areas of the Northeast, stretching from Long Island Sound to Maine, are threatened by a host of manmade and natural stressors. The issues involving coastal ecosystems and resources in the northeastern United States stem from complex interactions across a variety of temporal and spatial scales, and they demand integrated, interdisciplinary scientific responses. This science plan initiates such a multidisciplinary approach, combining the strengths of the Water, Geology, Biology, and Geography Disciplines within the U.S. Geological Survey (USGS), to address these complex ecological issues. This science plan integrates the strengths of these four disciplines and draws on input from scientists and managers 


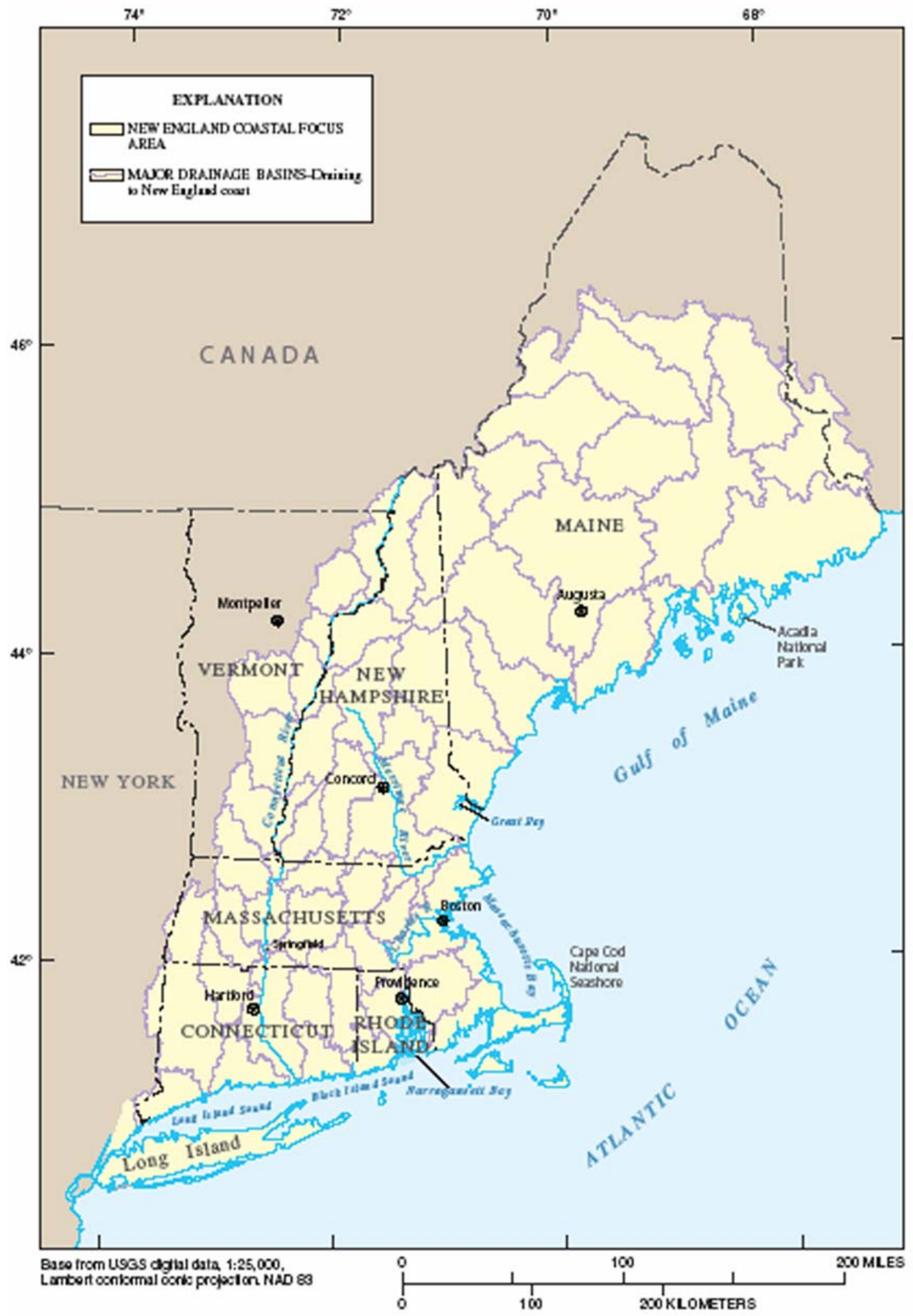

Map showing Northeast coastal area 
from Federal, State, local government, and nongovernmental cooperators and stakeholders.

The plan serves as a link between Bureau strategic goals, Bureau-wide programs, Eastern Region science priorities, and the actual interdisciplinary, relevant science currently underway in Northeast science centers (see appendices 2-4). This plan will guide implementation by the New England Discipline Managers Advisory Committee (NEDMAC) to formulate a strategy to build support for these science activities with Bureau program coordinators, Eastern Region management, and stakeholders from other Federal and state agencies, universities, and non-governmental organizations (see appendix 1).

\section{GEOGRAPHIC SETTING OF THE NORTHEAST COASTAL ECOSYSTEMS AND RESOURCE FOCUS AREA}

The Northeast coastal area encompasses the New England seaboard, extending from Long Island Sound to the rocky coasts of Maine and including the watersheds of the major and minor rivers, groundwater-dominated portions of the coast not drained by streams, the shoreline itself, nearshore ecosystems, and the continental shelf. This glaciated coast, with its diverse geomorphic mix of large sand-and-gravel aquifers, rockbound coasts, sandy beaches, salt marshes, embayments, major rivers, and critical estuary systems, is geographically distinct from the coastal environments along the rest of the eastern seaboard and responds in unique ways to natural and human-induced changes.

\section{USGS ROLE IN INTEGRATED SCIENCE IN THE NORTHEAST}

The USGS is strategically positioned to take a lead role in integrated science activities in the Northeastern United States as a multidisciplinary Federal science agency with a national scope that bridges the land-sea boundary. USGS scientists have the traditional expertise to characterize and model the land-water interface and nearshore and ocean environments. The USGS is known for its expertise in monitoring, mapping, modeling, and prediction of landscape processes and shoreline change. Bureau programs have compiled and maintain databases with long-term measurements of water, biological, and mineral resource data as well as maintained historical geologic and land-use records.

A primary ambition of the USGS is to directly involve customers and stakeholders in the application of science research to public policy questions. The USGS has a reputation for producing "good science," yet it also strives to make science relevant to key societal issues through strategic partnerships, outreach, and the communication of scientific results to the public. Multidisciplinary teams of USGS scientists and liaisons work with universities in the region and stakeholders from State and local organizations to focus efforts on genuine needs. The USGS is already distributed across the landscape in the Northeastern United States with offices and research teams in each State in order to interact with local stakeholders. Additionally, the USGS has established associations with research facilities in Woods Hole, Mass., and in Rhode Island.

\section{PRIORITIZING INTEGRATED SCIENCE ISSUES IN THE NORTHEAST}

A steering committee for the USGS Focus Area on Northeastern U.S. Coastal Ecosystems and Resources, with representation from each of the four USGS science disciplines, was established to identify integrated science priorities in the Northeast and to develop a science plan to address those issues. The committee organized a workshop, held in January 2003 at the University of Rhode Island Coastal Research Institute, to gather input from USGS scientists on major societal issues, scientific questions, and opportunities for USGS integrated science in the Northeastern coastal zone. The 72 participants from the USGS and over a dozen 


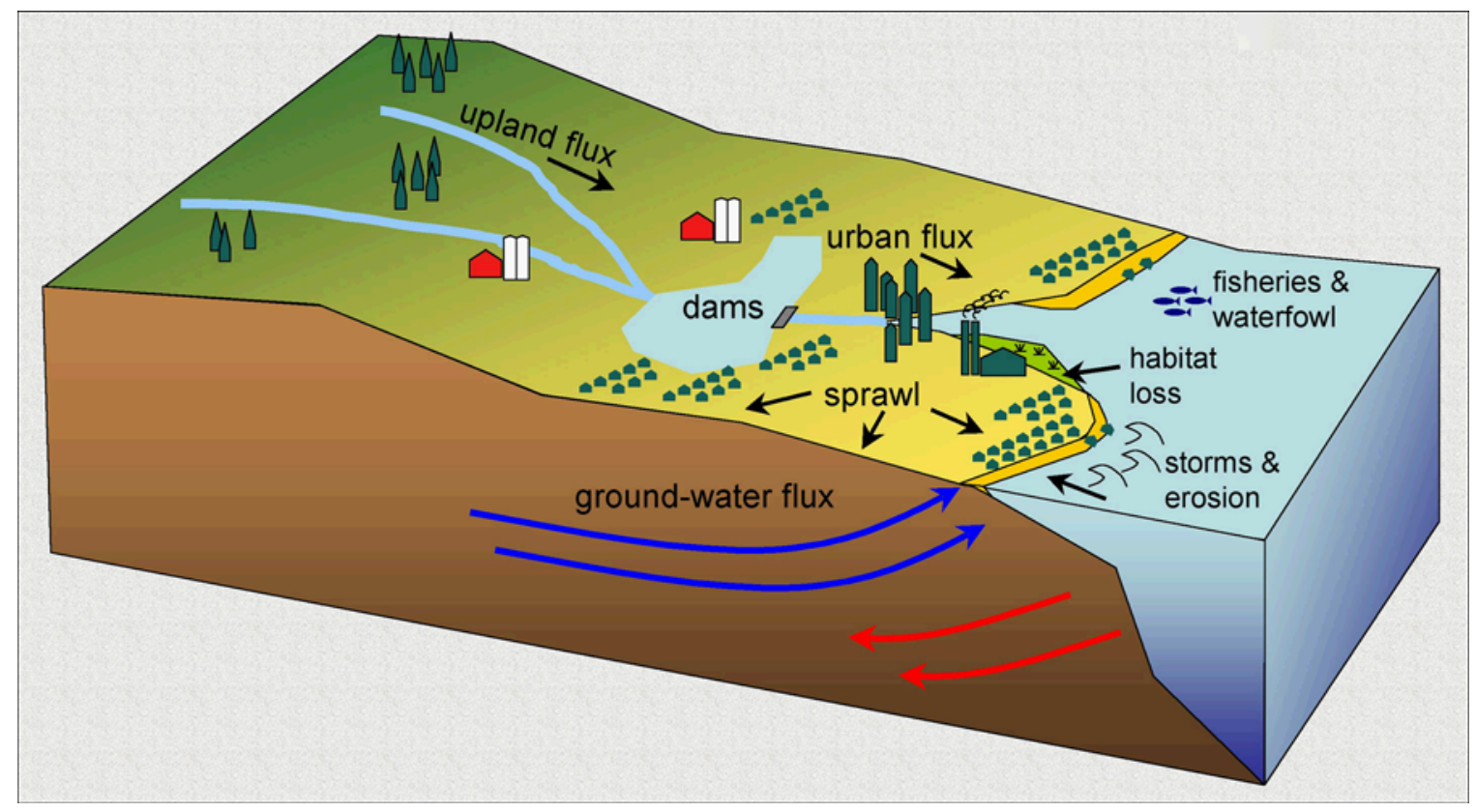

Schematic diagram showing important natural processes and human pressures that affect coastal ecosystems and resources of the Northeast.

partner organizations discussed and prioritized key issues associated with major threats in the coastal zone. The participants identified a number of geographic areas where interdisciplinary efforts linked to longer-term topical focus areas could be initiated. A writing team was charged with incorporating these priorities into an integrated science plan that capitalizes on the scientific strengths of the USGS disciplines and identifies expertise needed from outside collaborators. A summary of the January workshop may be found at: http://me.water.usgs.gov/coastal/.

\section{RATIONALE FOR INTEGRATED SCIENCE THEMES}

The three "big issue" themes identified as the most significant for USGS integrated science research in the Northeast coastal zone--fluxes, coastal hazards, urbanization/habitat change-cover an enormous range of scientific and societal issues. This integrated science plan does not attempt to exhaustively address all issues related to each theme. The objective is to focus multidisciplinary research activities on those issues for which USGS has a mandate to pursue, a proven record of sound disciplinary research, and willing partners or a customer base to offer support. The short-term actions proposed in this science plan are centered on locations and activities that offer USGS the highest visibility, yet also offer the best likelihood of success. The following rationale explains why these three themes are critical to integrated science activities in the Northeast coastal environments.

Fluxes of Water, Nutrients, Sediment, and Contaminants: The coastal zone of the Northeastern United States, from New York Harbor to Maine, includes some of the most highly urbanized areas of the Nation and is home to two of the oldest coastal cities in the United States, Boston and New York City. In the 375 years since European settlement, urban and agricultural development has led to profound shifts in land and water use and have dramatically affected the material fluxes to the ocean from the region. The integrity of coastal ecosystems in the region depends in part upon the historic and present-day fluxes of freshwater, sediment, nutrients, and contaminants entering 
the coastal waters from the mainland and the processing of these fluxes within the coastal zone. The Northeast has a long and welldocumented history of industrial development and changing land use. Understanding the relationships among historic land use, streamflow trends, past fluxes, and their ecological consequences will provide a better understanding of the controls on present-day nutrient fluxes as well as the ability to better predict coastal ecosystem response to future changes.

Coastal Hazards: Public awareness of coastal hazards is heightened immediately after a hurricane or major storm impacts a populated coastal area. After such events, the public often hears that the increasing rise in sea level - and the related increase in coastal erosion - is in conflict with the increasing population along the Nation's coasts. Evidence indicates that, in some coastal environments, marsh surfaces will not be able to keep pace with sea-level rise and will become inundated during the next century, causing a loss of wetland resources and the intrusion of seawater into coastal water supplies. A thorough understanding of coastal hazards will improve the estimates of total societal costs of coastal hazards, support engineering to minimize potential losses, and promote the public policy required to guide further coastal management. A critical additional goal is to increase efforts to educate the public and politicians with relevant and timely information about these issues.

Urbanization and Habitat Change: The Northeastern United States is the most highly developed and densely populated coastline in the Nation with about one-third of the Nation's coastal population. The coastal lands and waters are valued for recreation, fisheries, transportation, waste disposal, and commerce in addition to residence. In the Northeastern United States, recent decades have seen urban sprawl reaching out from metropolitan Boston and New York into formerly pristine regions. As forests and farms change to urban land uses, infrastructure increases, the amount of impervious surfaces in watersheds increases, and habitat is altered or destroyed. More people generate larger volumes of solid waste, greater industrial runoff, declines in water quality, and increased demands on wastewater treatment, drinking water, and energy supplies. Coastal urbanization and its accompanying pollution can have widespread effects on the sustainability of plant and animal populations in the Northeast and on the region's traditionally robust commercial and recreational fishing and shellfish economy. Increased human populations in coastal areas are subject to increased risk to health and property from both natural and human-induced changes to the environment. Nearshore habitats need careful monitoring to better understand impacts of siting cables, wind turbines, and other engineered structures near harbors and major population centers.

\section{LONG-TERM SCIENTIFIC ISSUES}

\section{Fluxes of Water, Nutrients, Sediment, and Contaminants}

Quantifying the passage of sediment, water, and associated solid and dissolved constituents through and along coasts and understanding the processes that drive these movements have been the major challenges confronting coastal scientists and will remain so. Coastal zones are productive and attractive because they are dynamic. To protect or restore dynamic coastal ecosystems and resources, the USGS should continue to support the science of coastal fluxes because the USGS has (1) a critical scientific mass, (2) special capabilities to integrate various coastal science disciplines, and (3) the ability to inform coastal resource managers on important decisions with regional (or larger) significance. As stated in documents prepared for the workshop that provided major input to this science plan, "the USGS, as the only multidisciplinary federal science agency spanning the land-sea boundary, has a unique responsibility to characterize fluxes and assess the consequences to coastal ecosystems.” The USGS has previous research experience, current staffing, and technological strengths to address several pressing questions critical to moving the science of coastal fluxes forward while at the same time informing urgent and costly ecosystem and resource management decisions. Unresolved 
problems and conflicts in the coastal zone also create opportunities for the USGS to pursue these scientific questions.

The USGS, in collaboration with its partners, should concentrate over the next 5 to 10 years on addressing the following flux-related research issues, organized into the following five topical focus areas:

1. Critical coastal wetland habitats: Coastal wetlands provide essential habitat for fish, crabs, shellfish, and migratory waterfowl. We need to understand the roles of freshwater and sediment flux in the function of natural salt marshes, so that (1) healthy marshes can be properly protected, (2) marsh loss can be slowed or reversed, and (3) marshes degraded by various human activities can be restored. Linkages between variations in ground-water discharge and quality and changes in the health and diversity of marsh vegetation are not well understood. In developed systems, fluxes of sediment and water must be affordably managed to optimize the quality of marsh habitat while still providing sufficient drinking water, recreationally appealing beaches, navigable harbors, and safe disposal of wastewater. Marsh habitat distribution has changed naturally through time and is likely to continue to do so in the future, but the ability to predict future evolution of salt marshes is in its infancy. The need is made more urgent by the threat of marsh drowning by rising sea level.

2. Distribution, movement, and fate of toxic substances: Contaminated sediments have been known to exist in rivers and coastal areas of the Northeast for decades and have created chronic human health risks and ecological degradation. It should now be possible, however, to use existing data on sediment quality to guide risk-based prioritization of future research on the fate of toxic substances in sediments of the region. Better science can be applied to containment and removal of toxic legacy sediments in industrialized areas and in dam reservoirs to maximize health benefits and minimize costs. Techniques to determine optimal geochemical and biological indicators need to be developed to monitor ecosystem recovery after remediation of degraded areas or to assess impacts during and after disturbance of contaminated sediments by dredging or construction. The USGS has a strong and recognized history of work on this topic, including large regional studies and focused process studies incorporating innovative sampling and analysis methods. The USGS should also be prepared to respond to research and mitigation opportunities created by future catastrophic releases of harmful substances (for example, oil spills).

3. Coastal aquifer interconnections with the sea: The critical role of coastal ground-water discharge in different types of coastal ecosystems such as sea-grass beds, salt marshes, and beaches has become clear within the last decade, but the details remain to be worked out. It has also been hypothesized that coastal ground-water discharge may play a role in coastal erosion, but this idea remains untested. Coastal aquifers can carry pollutants to coastal waters or provide conduits for saltwater intrusion to contaminate water-supply wells. The suite of tools available for studying submarine ground-water discharge and saltwater intrusion in different coastal settings such as barrier islands, lagoons, coastal bays, rocky coasts, and salt marshes has been greatly expanded in recent years, with the USGS leading much of this progress. Pressing questions remain about whether general models or realistic conceptual models of saltwater-freshwater interaction in the subsurface can be developed so that unstudied sites can be characterized and managed efficiently and affordably. Numerical models also hold great promise as tools for testing conceptual models of interaction as well as for integrating data from field tests.

4. Nutrient fluxes from wastewater: Wastewater is often considered the most significant source of nutrients, in terms of both quantity and impact, that cause eutrophication of estuaries and the coastal 
ocean in the Northeast. This assumption, however, has not been rigorously tested in many important settings. Differentiating natural and anthropogenic sources and variability of nutrient inputs is rarely straightforward. Seasonality of wastewater discharge may be an important aspect in the appearance of harmful algal blooms that has not been fully considered in many coastal settings. Although relative impacts of diffuse discharges of wastewater such as those that occur from septic systems in lowdensity residential areas are likely to affect ecosystems differently than the more concentrated discharge from treatment plant outfalls and infiltration basins, such comparative studies are rare, albeit essential, for regional wastewater management decisions. Water-supply and wastewater disposal issues are currently limiting development in many coastal communities, with increasing problems likely in the future. The multidisciplinary USGS mandate here is obvious.

5. River-seashore sediment interaction: Episodic events such as storms and spring freshet are important in creating and modifying watershed, shoreline, and nearshore sediment deposits, but their role relative to that of long-term prevailing winds and currents is generally difficult to assess. The time lag between release of sediments by human disturbance such as logging, agriculture, or fire and their transport through watersheds to estuaries and the coastal ocean is important to understand but is relatively unconstrained in most watersheds of the Northeast. Modification of watersheds and shorelines by construction or removal of engineered structures such as dams, jetties, or seawalls and other human alterations of the shoreline and nearshore such as dredging and beach nourishment affects the short- and long-term evolution of the sediment system. Insufficient baseline information makes it difficult to assess the impacts of many of these modifications and makes prediction of response risky. Current modeling, experimentation, and monitoring efforts should be expanded in the future to address these issues. The USGS has taken a leadership role in this area over the past decade, and opportunities continue to present themselves.

\section{Coastal Hazards}

The coastal zone is a heterogeneously diverse area that includes both areas subject to anthropogenic alterations and relatively undisturbed natural features. Human populations are growing faster in the coastal zone than in any other region of the United States, and the construction of buildings and infrastructure necessary to support this growing population is accelerating. Protection against and recovery from coastal hazards peculiar to the costal zone are becoming ever more costly.

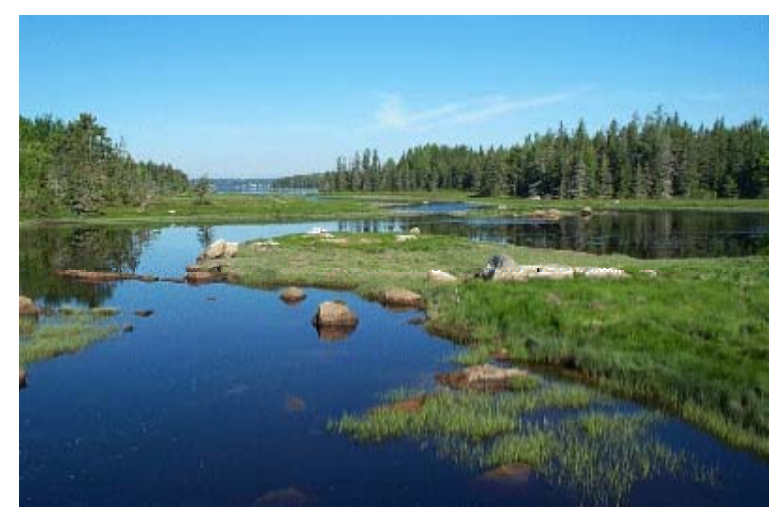

Wetlands habitat

Few environments are as biologically diverse and productive as those found in estuarine and wetland habitats. Estuaries and wetlands are important habitat for secondary production of fish and shellfish and hotspots of biological diversity. These habitats also play important roles in protecting the shoreline but are themselves faced with constraints on their sustainability.

The effects of coastal hazards are most visible in estuarine and open coastal habitats. This ocean/land interface is strongly influenced by the effects of various physical processes including temperature, ocean currents and dynamics, atmospheric storms, freshwater flows, and variations in rates of sea-level rise.

The increasing rates of sea-level rise and the potential increase in the frequency of hazardous 
storms accelerate coastal erosion rates and the loss of important wetland habitat as well as being in conflict with an increasing population and associated increase in development in the coastal zone. Understanding the dynamics of accelerating sea-level rise and hazardous storms, as well as the influence of long-term climate change on these processes, is critical for assessing risk and vulnerability of the coastal zone and developing and evaluating appropriate management strategies.

A policy-relevant research program directed toward understanding the risk associated with coastal hazards should include monitoring, an understanding of the impact of physical processes, and predicting changes and determining the mechanisms influencing those changes. Such a scientifically based risk assessment process should help decisionmakers incorporate the uncertainties posed by coastal hazards into long-term plans for natural resource management, property protection, and minimizing human loss. The USGS has a long history of work in the coastal zone and is known for its ability to utilize expertise from across the Bureau in developing integrated modeling, mapping, and decision-support programs that address both biological and physical processes. The USGS has implemented a classification of the relative vulnerability of different U.S. coastal environments to future sea-level rise (see Thieler and Hammar-Klose 2000; HammarKlose and Thieler, 2001), and considerable new work has focused on understanding the vulnerability of coastal wetlands throughout the New England region.

Long-term topical focus areas that the USGS should concentrate on over the next 5 to10 years include:

1. Sea-level rise: Substantial damage to human and biological populations, infrastructure, and natural resources such as wetlands can result from sea-level rise. The impact of sealevel rise on the processes sustaining coastal estuaries and wetland habitat, including the ability of coastal wetlands to maintain marsh surface elevation in the tidal range, shoreline inundation, and increased salinization of coastal embayments affecting fishery and shellfish populations, needs additional study. Where are the wetlands that are at greatest risk to increases in sea-level rise? Wetland loss will be largest where human development impedes the natural landward migration of wetlands in response to sealevel rise.

2. Hazardous storms: We need to better understand the impact of atmospheric storms on coastal erosion, especially erosion of barrier islands and shoreline by storminduced shoreline flooding and wetland loss. It is critical that we better understand the links between coastal geomorphic processes and habitat and ecosystem change. Longterm erosion adds greatly to the societal risks and costs in coastal areas. This erosion can be exacerbated by human activities that include dredging of ports and harbors, maintenance of tidal inlets, and damming of major rivers.

3. Responses to climate variability and change: We need to better understand how biological and ecological systems will respond to climate change and variability and intensive human activity. How can we characterize and reduce key uncertainties of the impacts associated with climate change and variability? The coastal zone may be the region of the Nation most vulnerable to long-term climate change. The coastal zone will have to contend with changing rates of sea-level rise and could be subjected to more frequent and intense storms. Responses to such physical processes could cause increased coastal flooding and erosion, higher storm surges, increased wind damage, and increased saltwater intrusion into coastal freshwater aquifers.

\section{Urbanization and Habitat Change}

USGS coastal studies in the southern part of the Northeast (Connecticut, Rhode Island, Massachusetts, and New Hampshire) should be targeted toward developing a better understanding of the long-term effects of 
industrialization, urbanization, and sprawl on natural resources and the environment. USGS coastal studies in the northern part of the Northeast (Maine) should be focused toward developing a better understanding of the effects of industry (such as paper mills and boatbuilding) and developing urbanization and sprawl on areas historically in a rural/small town setting.

The long-term topical focus areas under the theme of coastal urbanization and habitat change are:

1. Availability and quality of water resources: Although it is true that the Northeast is known for an abundance of water, the availability of this important natural resource is becoming more critical owing to continued coastal urbanization and sprawl. The USGS is uniquely prepared to map and model the distribution, flow, and transport characteristics of surface- and ground-water resources to better understand the impact of urbanization and sprawl on coastal watersheds -- in particular, the quantity and quality of these waters and the nature of their interactions in coastal marine environments such as wetlands, harbors, bays, and estuaries.

2. Impacts of urbanization on habitat health: The development of coastal urban centers and sprawl in the Northeast has had -- and continues to have -- a direct impact on the structure, function, integrity, and sustainability of coastal ecosystems. Interdisciplinary science opportunities for the USGS on the impact of coastal urbanization on habitat include the investigation, quantification, and monitoring of the:

a. Effects of streamflow depletion and water quality on habitat condition and ecosystem sustainability;

b. Impact on coastal ecosystems of nutrient loading to coastal waters from surfaceand ground-water, and atmospheric sources; c. Impact of invasive species on the structure, function, and sustainability of native plants and animals inhabiting coastal ecosystems; and,

d. Effectiveness of restoration efforts in salt marshes, eutrophied embayments, commercial and recreational fisheries and shellfish beds, and disturbed eel grass habitats affected by urban sprawl.

3. Impacts of Urbanization on Human Health: Continued development of coastal urban centers and urban expansion into formerly rural areas of the Northeast will challenge society's ability to protect residents and visitors from natural and manmade health risks. The coastal zone (at ports of entry) is also the site of import of most invasive species, including pathogens such as Lyme disease and West Nile virus that affect not only terrestrial biota but human health as well. The USGS is well positioned to study the sources, transport mechanisms, and fates of toxic metals, volatile organic compounds, pesticides, pharmaceuticals, and pathogens in surface and ground water, to provide a better understanding of the impacts of the urban environment and the recreational use of urban habitats on human health.

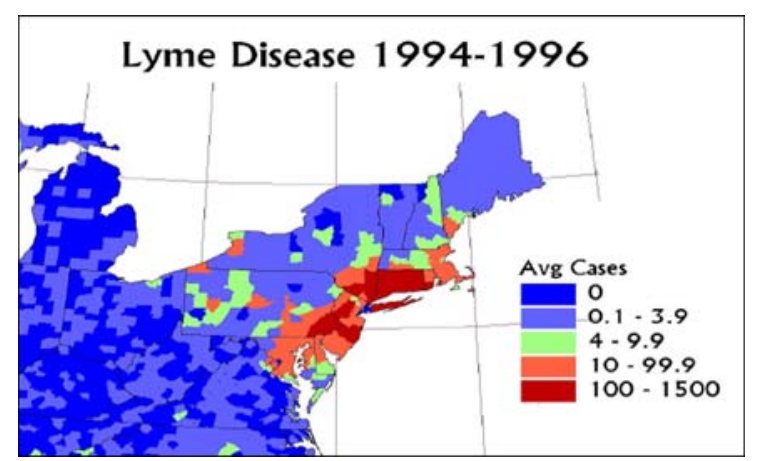

Graph showing incidence of Lyme disease, 19941996

4. Coastal Contamination: Urban harbors in the Northeast sequester a legacy of sediment contaminants associated with sewage and industrial discharges. Seven of the top 100 ports in the United States are in the Northeast: (\#, millions of tons of cargo 
handled in 2001): Portland, Me. (\#26, 28.5), Boston, Mass. (\#33, 20.6), New Haven, Conn. (\#52, 9.9), Providence, R.I. (\#57, 9.0), Bridgeport, Conn. (\#81, 4.6), Portsmouth, N.H. (\#82, 4.4), and Fall River, Mass. (\#93, 3.4). In addition, dozens of small coastal embayments throughout the Northeast are experiencing elevated nutrient (especially nitrogen) and bacteria loading from suburban development on their shores. The distribution of these contaminants, their toxicological effects, and the results of recent harbor restoration efforts are all areas of important potential study for the USGS.

\section{GEOGRAPHIC FOCUS AREAS FOR INTEGRATED SCIENCE}

The following geographic areas were selected from the discussions at the January workshop as likely sites in which to focus short-term integrated science efforts. These areas were chosen because of the prominence of important scientific issues, the ability of the USGS to address these issues within a short time frame under current funding priorities, the existence of ongoing USGS projects in these areas, prior partnerships and customer support, and the likelihood of short-term success.

\section{Gulf of Maine}

\section{Acadia National Park, Maine}

Acadia National Park, encompassing more than 40,000 acres of land on Mount Desert Island in Maine, is one of the largest publicly owned and protected natural areas in the Northeast. Mount Desert Island and the surrounding mid-coast areas of Maine are currently experiencing increased residential development and community growth. USGS integrated science studies (Water and Biology Disciplines) have focused on identifying and predicting some of the consequences of this developmental pressure in and around Acadia National Park. In recent years, water-resources and habitat-related studies have sought to quantify nutrient loads to estuaries, determine the impacts of nutrient enrichment on estuarine ecosystems, assess the degradation of ground-water quality, develop wetland monitoring programs, and prioritize coastal lands for easement protection. The coastal region encompassing Acadia National Park provides a unique opportunity for the USGS to conduct integrated studies of the impacts of rapid coastal development in a coastal region containing a variety of protected natural environments and habitats.

\section{Great Bay/Piscataqua River Estuary}

This system is located along the Maine-New Hampshire border and is part of the National Estuarine Research Reserve System. It also includes the Great Bay National Wildlife Refuge. The system has a 900-square-mile drainage that includes seven rivers and a variety of aquatic habitats including shorelines of exposed bedrock, mudflats, salt marshes, and eelgrass. The Great Bay watershed is one of the fastest growing regions in New England and is experiencing the classic problems associated with urban growth in the coastal environment, including water shortages, degradation of water quality, loss and fragmentation of habitat, and development in zones of coastal hazard. The area supports diverse uses, including the Portsmouth seaport, the Portsmouth Naval Shipyard, and the Pease International Tradeport (on the former Pease Air Force Base [AFB]), all of which have contamination legacies.

The USGS, in collaboration with the University of New Hampshire, has conducted preliminary estimates of ground-water inflows and nitrogen loading from ground water to the Great Bay. Side-looking sonar scans of the bay have been conducted, and fracture-correlated lineaments and ground-water heads have been mapped. The USGS has also conducted intensive geophysical studies of fractured bedrock and contaminant transport at the former Pease AFB.

The Great Bay watershed in New Hampshire is currently the focus of a USGS water-resources sustainability investigation to examine the impact of urbanization and increasing water withdrawals on ground- and surface-water resources in the New Hampshire seacoast region. At the same time that demand on ground- and surface-water supplies have been 
increasing, other development-related changes have created impervious surfaces that decrease recharge to aquifers. Additional research is needed to examine the impact of sea-level rise on freshwater fluxes, ground-water supply, and saltwater intrusion into fractured-bedrock aquifer systems in the region. The impacts of these changes on the sustainability of the ground-water resources and on ability to maintain streamflows, coastal wetlands, and fresh ground-water discharges needed for sensitive coastal habitats are important topical focus areas for the USGS. The regional fractured-bedrock aquifer system is also subject to potential saltwater intrusion from excessive ground-water withdrawals and sea-level rise, topics of possible urban concern that have not been explored in the eastern United States. This area is also a region where arsenic concentrations in ground water from the fractured-rock aquifer system are among the highest in the Nation. USGS research into spatial and temporal variability and geochemical mobilization processes for arsenic is needed.

\section{Merrimack River, Estuary, and Adjacent Salt Marsh Systems}

The Merrimack River, which has its headwaters in the White Mountains of New Hampshire and its mouth at the historic seaport of Newburyport, Mass., has played an important role in New England history. The first large-scale textile mills in the Nation were constructed in Lowell and Lawrence, Mass., and Manchester, N.H. This long urban and industrial history has generated a need for several types of information that the USGS is well-positioned to provide: (1) the quantity and toxicity of sediment impounded behind dams on the river and its potential for transport to the estuary and shelf after damremoval, (2) the importance of the Merrimack River as a nutrient source to the Gulf of Maine and the potential role of these fluxes in promoting harmful algal blooms in nearshore areas, and (3) the major sources of fecal bacteria presently impacting shellfish waters in Merrimack estuary and adjacent tidal flats. New USGS work, building upon existing work done by the Water, Geology, and Biology Disciplines in the Lower Merrimack region, could be conducted in cooperation with the Lowell National Historic Park of the National Park Service (NPS).

The Great Marsh, which extends southward from the Merrimack River estuary to Cape Ann, Mass., is the largest coastal wetland in New England. A second system, the SeabrookHampton Marsh, extends northward from the Merrimack estuary into New Hampshire. Together, these systems comprise over 25,000 acres of estuary habitat and 15,000 acres of salt marsh near the mouth of the Merrimack River. USGS work here, including involvement by Maine-based Biology Discipline staff from the Patuxent Wildlife Research Center, could provide a broader regional perspective to existing and planned studies in the area, including the Water Discipline's modeling studies of the watersheds that feed Plum Island Sound and the National Science Foundation (NSF)-sponsored Long Term Ecological Research site in the Sound. Related involvement in marsh restoration work throughout the Gulf of Maine (for example, Sagamore Marsh and Hatches Harbor [Cape Cod region], Great Bay [New Hampshire], and Acadia National Park [Maine]) should be continued as a logical component of this coastal wetlands effort, in cooperation with the U.S. Fish and Wildlife Service (USFWS), the NPS, and the U.S. Army Corps of Engineers (USACE).

\section{Massachusetts Bay}

Boston Metropolitan Area: Charles River/ Boston Harbor/Massachusetts Bay

The Boston metropolitan area contains 3.4 million people, 25 percent of the region's population. Ongoing fluxes of nutrients and other contaminants associated with this urban region, as well as the legacy of contaminated sediments in the rivers and harbor areas of Boston, make it almost mandatory for the USGS to continue its support of this area as a major focus of research. Specifically, the USGS should maintain or expand work related to the Environmental Protection Agency's (EPA) goal of a "swimmable fishable Charles" by 2005. Important needs include assessing stormwater loads and the effects of remaining combined 
sewer overflows (CSOs) as well as continuing its ongoing assessment of the fate and transport of contaminants in Boston Harbor and Massachusetts Bay. The recent completion of a $\$ 4$ billion project to improve Boston's sewage treatment system provides a unique scientific opportunity to observe the recovery of a degraded ecosystem. Bringing a stronger biological science component into these projects should be a priority.

Urbanization and habitat change are also important issues in the Boston metropolitan area. Urban sprawl has spread the growing human population over large areas of formerly forest and agricultural land, fragmenting wildlife habitats and altering the pre-development water cycle. Restoration of the urban core is also proceeding rapidly, as shown by a $\$ 15$ billion project to depress the elevated highway along the city's waterfront ("the Big Dig," currently the largest public works project in the Nation) and the $\$ 300$ million effort to restore the water quality and parklands of the Charles River. The USGS (Water and Geology Disciplines) has been active in a wide variety of Boston-area projects, including water-resources modeling in the Charles River headwaters, stormwater modeling and bacteria source typing in the Lower Charles watershed, and hydrodynamic modeling and sediment contaminant mapping in Boston Harbor and Massachusetts Bay. The USGS (Geography Discipline) has also been at the forefront of mapping efforts related to homeland security. The USGS is in an excellent position to conduct integrated studies of urbanization in this critical urban area of the Northeast.

\section{Cape Cod}

In the past 50 years, Cape Cod has experienced a greater degree of urban growth than any coastal area in the Northeast. This growth has occurred in shoreline areas subject to erosion as well as on formerly undeveloped inland areas. Development here is a major concern because these inland areas are the primary recharge areas for the underlying sand-and-gravel aquifer. The Cape Cod aquifer is an EPA-designated SoleSource Aquifer because residents depend completely upon ground water for their water supply. The USGS has a major research and facilities presence on Cape Cod. Numerous USGS scientists have conducted fundamental and applied research on ground-water flow and chemistry, glacial geology, shoreline change, and near-shore processes over the past 40 years.

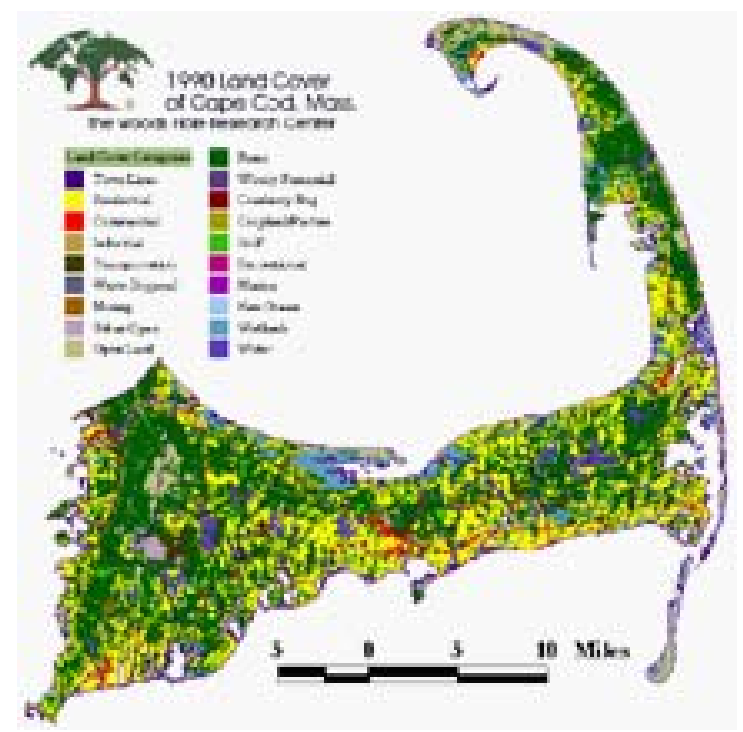

Map showing 1990 Cape Cod land cover

USGS scientists also have long-term research activities in partnership with the National Park Service within Cape Cod National Seashore. Research has focused on the impact of sea-level rise and coastal erosion on wetland systems and shoreline persistence, the sustainability of coastal water bird populations, the importance of tidal exchange to salt marsh structure and function, and the ecological impacts of groundwater withdrawal. A major goal of a USGS coastal initiative in the Northeast should be to integrate these efforts across the disciplines to better understand the impacts of coastal sprawl, ground-water flow, and hazardous storms and sea-level rise on the sustainability of Cape Cod ecosystems and environments.

\section{Southern New England}

\section{Narragansett Bay}

The Narragansett Bay watershed, encompassing more than 1,600 square miles in Rhode Island and Massachusetts, is home to nearly two 
million people in 100 cities and towns. Several significant urban centers and areas of developing coastal sprawl are located along Narragansett Bay or in its watershed. Worcester, Mass., the third largest urban area in the Northeast, is located in the headwaters of the Blackstone River, which empties into the head of Narragansett Bay. Providence, R.I., the second largest urban area in the Northeast and a major port, is located on upper Narragansett Bay. The USGS has a great opportunity to integrate the research being conducted by the various disciplines in Narragansett Bay. The Water Discipline is conducting watershed studies; Geology is examining coastal sediments; coastal marsh studies are being conducted by the Biology Discipline; Geography's 133 cities initiative applies to the bay as well. These studies, in cooperation with other Federal agencies (EPA, USACE, the Department of Defense, and the National Ocean and Atmospheric Administration [NOAA]), State agencies, non-governmental organizations, and academia (URI Coastal Institute), would examine the effects, across a gradient of environmental and ecological conditions, of coastal urbanization, nutrient flux, coastal marsh integrity, and estuarine sustainability on this important system.

\section{Southern New England Coastal Ponds}

A series of small embayments, partially or totally closed by spits and barriers, exists along most of the coast of southern Massachusetts, Rhode Island, and Connecticut. A regional study of the role of ground-water discharge in these systems in highly developed and relatively pristine settings would provide important information for local and regional resource managers, who are tasked with guiding development along the coastline while protecting ecosystems and the recreational appeal of these settings. Although much isolated work has been done in these systems by hydrogeologists, ecologists, and coastal oceanographers, the role of ground water in these coastal ponds is consistently identified as a critical data gap. Information is also needed on the thresholds of ecosystem response to groundwater inputs and potential ecological ramifications, including specific consideration of the role of these systems as fish nursery habitat. It is significant that many of these coastal ponds also provide habitat for migratory waterfowl and are managed as parts of NOAA's National Estuarine Research Reserve system (Waquoit Bay), the NPS system (Cape Cod National Seashore), and the USFWS's National Wildlife Refuge system (for example, McKinney, Sachuest Point/Ninigret/Trustom Pond, and Monomoy).

\section{Coastal Department of Defense Facilities}

Active and closed defense facilities located on or near the coast in the Northeast have impacted local environments in unique ways. Naval facilities (especially New London Submarine Base/Electric Boat, Newport Naval Base, and Portsmouth Naval Shipyard) and air bases (Brunswick Naval Air Station, former Otis AFB, and former Pease AFB) have produced diverse and sometimes exotic contaminants from spills, landfills, fuel storage, wastewater disposal, maintenance, shipbuilding, and other activities that pose unique scientific problems. As a Federal bureau, the USGS has often supplemented EPA and contractor efforts on these sites by applying specialized or experimental techniques as well as by addressing particularly contentious issues as an objective and scientifically sophisticated third party. A coordinated USGS approach to the study of sediment and coastal aquifer contamination at these sites might improve effectiveness of remediation, as well as produce insights for basic science and provide additional support for other Federal agencies

\section{Connecticut River/Long Island}

The main stem of the Connecticut River is 410 miles long and drains an area of approximately 7.1 million acres. The river drops over 2,400 feet, has a mean freshwater discharge of 21,280 cubic feet per second, and drains significant portions of four states -- Vermont (41 percent), New Hampshire (34 percent), Massachusetts (33 percent) and Connecticut (29 percent). It is the largest watershed in New England and the 
source of 70 percent of Long Island Sound's fresh water.

The size, interstate location, and history of previous USGS work in the river make it a logical choice for integrated mountains-to-sea flux studies of water and sediment, integrated with ecological studies of anadromous fish and migratory birds. Natural resource management

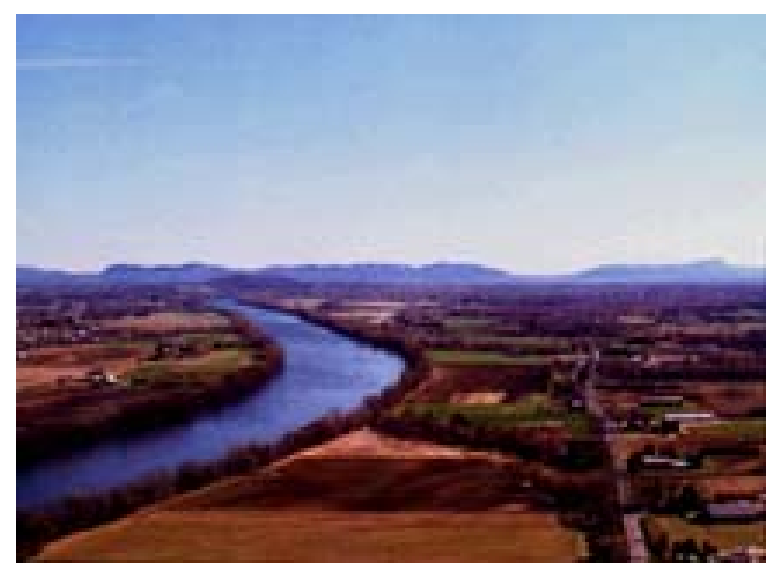

\section{Connecticut River Valley}

agencies, water-resource users and interested non-governmenal organizations seek scientific information to guide decisions about sustainable human uses that are compatible with maintaining functional ecosystems in a heavily populated area.

Examples include:

- Nitrogen management and establishment of total maximum daily load (TMDL) criteria, including understanding non-point sources and in-stream loss of nitrogen caused by denitrification.

- The role of dams that impound significant amounts of sediment (especially toxic sediment) or that have recently been removed or are under consideration for removal.

- Integration of existing sediment and contaminants data from Long Island Sound with watershed data (a major priority).

- The response of the marsh surface to changes in the rates of sea-level rise and the implications for change in the vegetative composition of these marshes

- Sources of bacteria presently impacting coastal areas of Long Island Sound used for shellfishing and recreation.

- Sediment dynamics in Long Island Sound in the vicinity of its mouth.

- Water availability and quality through changes in land use and economic conditions associated with development and their effects on the balance of natural systems within the watershed and associated portions of Long Island Sound.

The last topic includes many, if not most, aspects of the preceding topics and has been developed as an integrated science project for Fiscal Years 2004 and 2005, funded by the Office of the Eastern Region Director.

\section{ACTION PLAN RECOMMENDATIONS}

The items listed below are suggested actions that can help achieve the goals of this plan and advance the priorities of each of the three science themes described above. Science actions are listed first, followed by management and communication actions. NEDMAC will be responsible for the development of an implementation plan that will prioritize and add detail to most of these action items, including timeframes and responsible parties.

\section{SCIENCE}

\section{Fluxes}

1. Develop the ability to quantify important sources, sinks, and biological interactions of sediment and fresh water in salt marsh habitats with the goal of optimizing marsh management and restoration and predicting marsh evolution.

2. Increase our understanding of the influence of sediment geochemical processes on benthic communities present in moderately to very contaminated harbor sediments by conducting field and laboratory experiments.

3. Transform the existing marine sediment database being developed for the Northeast 
into a useful tool for research and management.

4. Make the development and testing of numerical models of sediment transport and saltwater-freshwater interaction in the subsurface a priority.

5. Continue development and application of analytical techniques that make it possible to (a) identify discrete sources of pollutants by various innovative fingerprinting techniques (bacterial DNA, isotopic ratios of heavy metals, isotopic nutrient tracers) and (b) follow their movement through ecosystems.

\section{Hazards}

1. Develop vulnerability assessments for specific geographic priority areas.

2. Monitor shoreline change in National Parks and coastal refuges.

3. Develop a consistent topographybathymetry database.

4. Develop better models of the susceptibility of coastal wetlands to sea-level rise.

5. Develop a framework for interdisciplinary research that provides a better understanding of how sea-level rise, flooding of coastal embayments, and loss of wetlands will affect economically important fish populations.

6. Develop models that predict the impact of changing storm frequency on coastal erosion.

7. Develop decision support models that utilize web technology, spatial data, and visualization to identify areas at risk from coastal hazards.

8. Determine how predicted changes in climate and climatic variability may affect coastal habitat restoration efforts and how these impacts can be mitigated.

\section{Urbanization}

1. Continue long-term monitoring, assessment, and evaluation of coastal water resources, habitat health, and contamination in urban watersheds and coastal environments.

2. Develop geographic information system (GIS) coverages to provide insights into past, present, and future trends of coastal urbanization and sprawl in the Northeast and their impacts on the coastal zone.

3. Develop seamless bathymetric/topographic and geologic coverages for the Northeast and its adjacent continental shelf to make possible integrated modeling efforts across the land/sea interface in support of coastal planning and management efforts in coastal ports, towns, and recreational areas.

4. Develop a detailed bedrock and surficial geology map coverage of the Northeast to use in better understanding the impacts and demands of coastal development on water quality and availability in coastal aquifers and watersheds.

5. Develop a better understanding of the linkage among current and past land-use practices to water, sediment concentrations, and biological communities to provide insights into past, present, and future impacts of coastal urbanization and sprawl on the coastal zone in the Northeast.

\section{MANAGEMENT AND COMMUNICATIONS}

\section{Internal Science Management and Planning}

1. Define metrics for evaluating progress on execution of this plan and assign the task of regular evaluation to an individual or committee.

2. Review and update this science plan on a biannual basis relative to \#1, possibly in association with the meeting described below. Pay particular attention to developing issues such as marine wind farms and dam removal.

3. Develop a specific mechanism by which the priorities identified in this plan can be (a) incorporated into the USGS science prospectus and (b) used to evaluate proposals received through the BASIS+ system.

\section{Internal Science Information Exchange and} Collaboration

1. Prepare annual progress reports on significant regional science achievements related to the focus of this plan. E-mail to USGS scientists and managers and post on web page (see below). 
2. Develop and maintain a web-based catalog of science projects being conducted in the region that will provide easy access to current work and expertise in all disciplines.

3. Encourage temporary or permanent colocation of scientists from multiple disciplines at USGS science centers in the region.

4. Establish a biannual one-day Northeast science exchange workshop to be hosted on a revolving basis by Northeast regional USGS centers where scientists can highlight recent work in the region in short oral presentations and posters. The meeting will take place in January or February to allow scientists from different disciplines to collaborate in preparation of proposals for submission in the spring and for joint summer field efforts.

5. Develop an award to be presented annually to USGS scientists working in the region whose work performed or products released in that calendar year were exemplary in integrating multiple disciplines in scientific problem solving.

\section{External Relationships and Communications}

1. Increase the visibility of USGS contributions and ongoing investigations to Federal, State, and local government officials (and their staff), including senators and representatives, governors, mayors, and selectmen. Particularly highlight outcomes and efforts producing cost savings, generating revenue, or having immediate human benefit.

2. Build better collaborative relationships with other Federal agencies (USFWS, NPS, USACE, EPA, NOAA, NASA, and so on), State and municipal agencies (State geological surveys, departments of environmental management, parks and recreation agencies), academic institutions, research laboratories, media outlets, and trade groups (fishing, tourism, development, utilities, transportation, environmental consulting, environmental law) working in the Northeast. Formalize contacts and distribution of science plans, press releases, and relevant publications and continue to include collaborators in the USGS science planning process.

3. Fully engage in regional efforts that fit the goals and objectives of the USGS science framework for New England coastal research. In particular, participate, as able, in the New England Region Implementation Team (NERIT) of Coastal America. Also foster growth of the new North Atlantic Coast Cooperative Ecosystem Study Unit (CESU), directed by the University of Rhode Island Coastal Institute.

4. Develop stronger relationships with entities, such as environmental non-governmental organizations, in the region that manage substantial natural areas (over 2 million acres in New England). This includes but is not limited to the Audubon Society $(>45,000$ acres), The Nature Conservancy (750,000 acres), the Society for the Protection of New Hampshire Forests (120,000 acres), Trustees of Reservations in Massachusetts (35,000 acres), and umbrella organizations such as the Land Trust Alliance.

5. Maintain contact with regional, national, and international environmental advocacy and policy groups such as the Gulf of Maine Council, the Conservation Law Foundation, the Natural Resources Defense Council, the Sierra Club, theWorld Wildlife Federation, Environmental Defense, and the John Heinz Center for the Environment. 


\section{SELECTED REFERENCES}

Beach, Dana, 2002, Coastal sprawl-The effects of urban design on aquatic ecosystems in the United States: PEW Oceans Commission, Washington D.C., 40 p.

Bookman, C.A., Culliton, T.J., and Warren, M.A., 1999, Trends in U.S. coastal regions, 1970-1998-Addendum to the proceedings, "Trends and Future Challenges for U.S. National Ocean and Coastal Policy": U.S. Department of Commerce, National Oceanic and Atmospheric Administration, National Ocean Service, Special Projects Office, 31 p.

Bricker, S.B., Clement, C.G., Pirhalla, D.E., Orlando, S.P., and Farrow, D.R.G, 1999, National Estuarine Eutrophication Assessment: Effects of Nutrient Enrichment in the Nation's Estuaries: Silver Spring, MD, U.S. Department of Commerce, National Oceanic and Atmospheric Administration, National Ocean Service, Special Projects Office and the National Centers for Coastal Ocean Science, 71 p.

Culliton, T.J., 1998, Population-Distribution, density and growth: Silver Spring, MD, U.S. Department of Commerce, National Oceanic and Atmospheric Administration, 1998 on-line at URL: http://state_of_coast.noaa.gov/bulletins/html/pop_01/pop.html

Doyle, Martin W., Emily H. Stanley, Jon M. Harbor, and Gordon S. Grant, 2003, Dam removal in the United States: Emerging needs for science and policy, Eos, Transactions, American Geophysical Union, 84(4): 29, 32-33.

Ewing, Reid, Pendall, Rolf, and Chen, Don, 2002, Measuring sprawl and its impact: Washington D.C., Smart Growth America, $42 \mathrm{p}$.

Graf, William, et al., 2002, Dam Removal-Science and Decision Making: Washington, D.C., The Heinz Center for Science, Economics, and the Environment, 221 p.

Hammar-Klose, E.S., and Thieler, E.R., 2001, Coastal vulnerability to sea-level rise; A preliminary database for the U.S. Atlantic, Pacific, and Gulf of Mexico coasts: U.S. Geological Survey Digital Data Series DDS-68, one CD-ROM (Available online at http://pubs.usgs.gov/dds/dds68/)

McGrath, David, 2000, 2025 Urban Land Area Forecasts for the Top 25 Coastal Metropolitan Regions: presented at Coasts at the Millennium, the 2000 Coastal Society Conference, July, 2000, Portland, OR.

National Research Council, 1997, Contaminated sediments in ports and waterways-Clean-up strategies and technologies: Washington D.C., National Academy Press, 320 p.

National Research Council, 1999, Science for decisionmaking-Coastal and marine geology at the U.S. Geological Survey: Washington D.C., National Academy Press, 113 p.

National Research Council, 2000, Clean Coastal Waters: Understanding and Reducing the Effects of Nutrient Pollution: Washington D.C., National Academy Press, 405 p.

Perry, M.J., and Mackun, P.J., 2001, Population change and distribution: Washington D.C., U.S. Census Bureau, Census 2000 Brief C2KBR/01-2, 7 p.

Platt, David, 1998, Rim of the Gulf: Restoring Estuaries in the Gulf of Maine, Mainewatch Institute \& Island Institute, $145 \mathrm{p}$.

Thieler, E.R., and Hammar-Klose, E.S., 2000, National assessment of coastal vulnerability to sea-level rise, Preliminary results from the U.S. Atlantic Coast: USGS Open File Report 99-593.

U.S. Army Corps of Engineers, 2001, Port Ranking by Cargo Volume, 2001; U.S. Army Corps of Engineers, Navigation Data Center

U.S. Environmental Protection Agency, 2001, National Coastal Condition Report: Washington D.C., Office of Research and Development/Office of Water, EPA-602/R-01/005, 204 p.

U.S. Geological Survey, 2001, The environment and human health-USGS science for solutions: U.S. Geological Survey Fact Sheet FS-054-01, 2 p.

Williams, S.J., and Thieler, E.R., 2002, Sea-level change-A workshop to define science needs and future USGS research directions: Sound Waves-Coastal Science and Research News from across the USGS, November 2002 [http://soundwaves.usgs.gov/2002/11/meetings.html] 
Appendix 1. Northeast Coastal Long-Term Integrated Science Priorities and Partners, Cooperators, and Stakeholders

Crosswalk: Northeast Coastal Long-Term Integrated Science Priorities and Partners, Cooperators, and

Stakeholders

Fluxes: Water, Nutrients, Sediment, and Contaminants

Critical coastal wetland habitats

Remediation of toxic sediments

Coastal aquifer interconnections with the sea

Nutrient fluxes from wastewater

River-seashore sediment

interaction

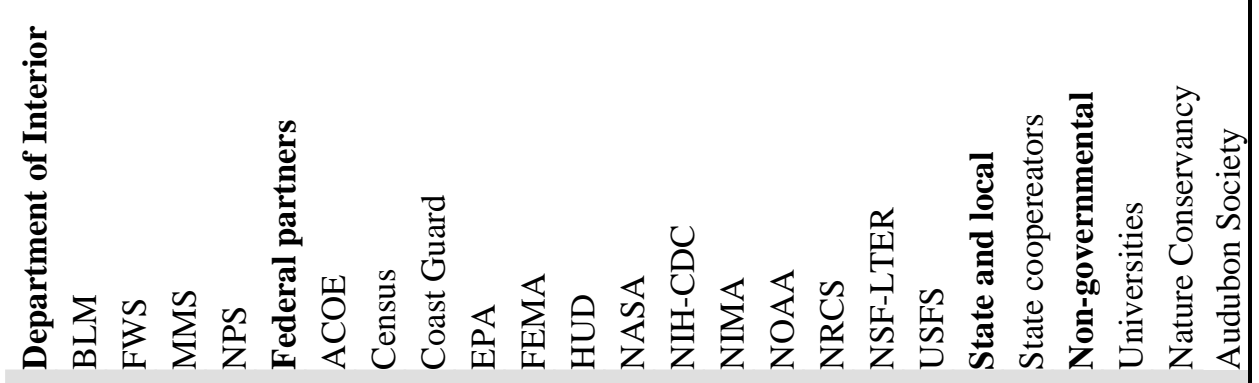

Coastal Hazards

Sea-level rise

Hazardous storms

X $\quad$ X

X $\quad$ X

X

X X

X X

$\begin{array}{lllll}\mathbf{X} & \mathbf{X} & \mathbf{X} & \mathbf{X}\end{array}$

$\mathrm{x}$

$\mathbf{X}$

X $\quad \mathrm{X}$

X $\quad$ X

$\mathbf{X}$

X $\quad \mathbf{X}$

$\mathbf{X}$

$\mathbf{X}$

X $\quad$ X

X

X

$\mathbf{X}$

X X

X $\quad$ X

Responses to climate variability and change

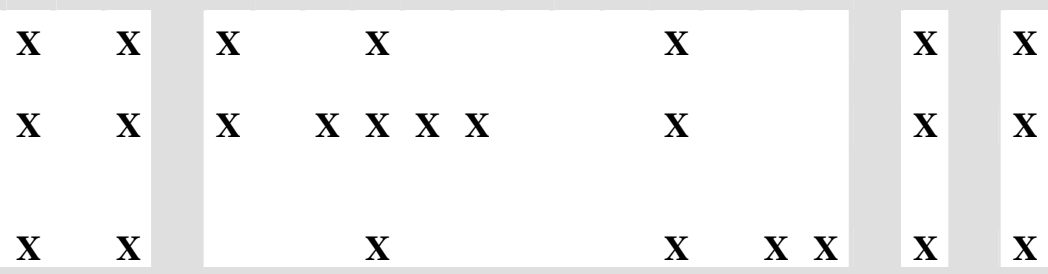

\section{Urbanization and Habitat}

Change

Water resources

Habitat health

X $\quad$ X

$\mathrm{X}$

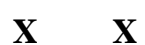

X

X

X $\quad$ X

$\mathbf{X}$

$\begin{array}{lllllll}\mathbf{X} & \mathbf{X} & \mathbf{X} & \mathbf{X} & \mathbf{X} & \mathbf{X}\end{array}$

$\mathrm{X}$

$\begin{array}{lllll}\mathbf{X} & \mathbf{X} & \mathbf{X} & \mathbf{X} & \mathbf{X}\end{array}$

$\mathbf{X}$

\begin{tabular}{lll}
$\mathbf{X}$ & $\mathbf{X}$ & $\mathbf{X}$ \\
\hline
\end{tabular} 
Appendix 2. Northeast Coastal Long-Term Integrated Science Priorities and Bureau Programs

Crosswalk:

Northeast Coastal Long-Term

Integrated Science

Priorities and

Bureau Programs

Fluxes: Water,

Nutrients,

Sediment, and

Contaminants

Critical coastal

wetland habitats

Remediation of

toxic sediments

Coastal aquifer

interconnections

with the sea

Nutrient fluxes

from wastewater

River-seashore

sediment

interaction

Coastal Hazards

Sea-level rise

Hazardous storms

Responses to

climate variability

and change

Urbanization and

Habitat Change

Water resources

Habitat health

Human health

Coastal

contamination

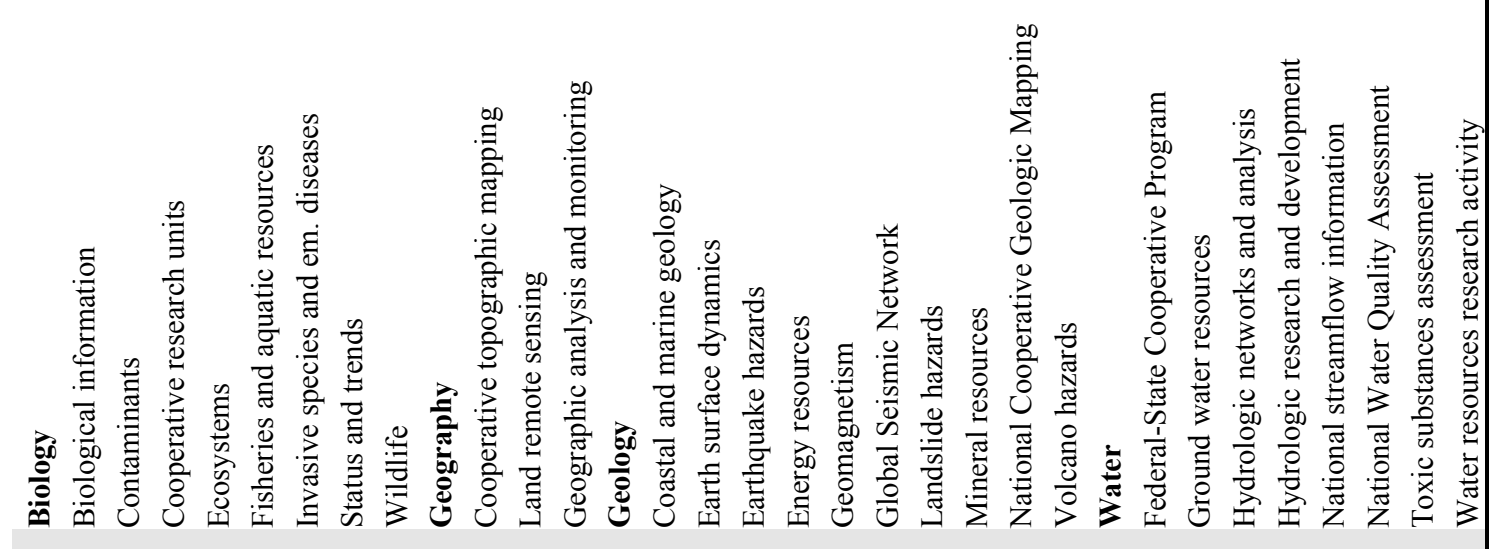

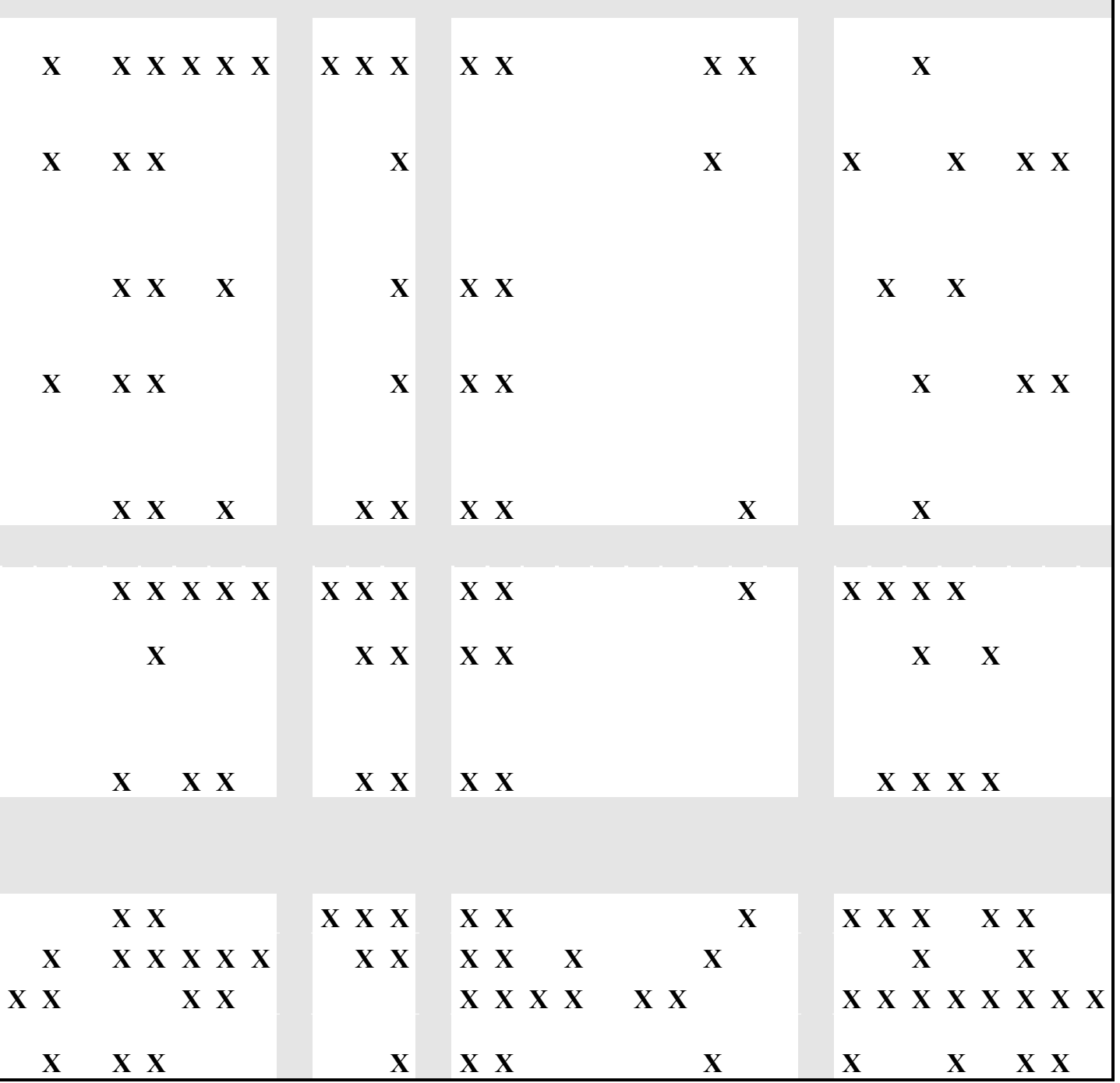


Appendix 3. Northeast Coastal Long-Term Integrated Science Priorities and Bureau Integrated Science Themes

Crosswalk: Northeast Coastal Long-term Integrated Science Priorities and Bureau Integrated Science Themes

Fluxes: Water, Nutrients, Sediment, and Contaminants

Critical coastal wetland habitats Remediation of toxic sediments Coastal aquifer interconnections with the sea Nutrient fluxes from wastewater River-seashore sediment interaction Coastal Hazards

Sea-level rise Hazardous storms Responses to climate variability and change Urbanization and Habitat Change Water resources Habitat health Human health Coastal contamination

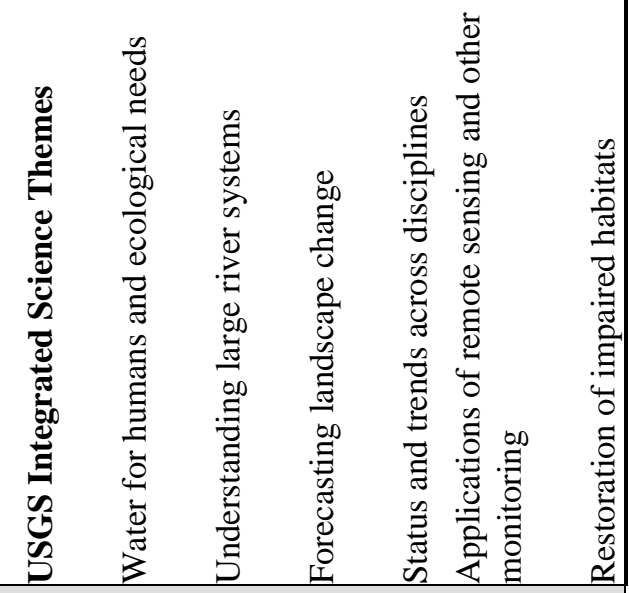

\begin{tabular}{llllll} 
& $\mathbf{X}$ & $\mathbf{X}$ & $\mathbf{X}$ & $\mathbf{X}$ & $\mathbf{X}$ \\
$\mathbf{X}$ & $\mathbf{X}$ & $\mathbf{X}$ & & & $\mathbf{X}$ \\
$\mathbf{X}$ & & & & & $\mathbf{X}$ \\
$\mathbf{X}$ & & $\mathbf{X}$ & & & $\mathbf{X}$ \\
$\mathbf{X}$ & $\mathbf{X}$ & $\mathbf{X}$ & & $\mathbf{X}$ & $\mathbf{X}$ \\
& & & & & \\
$\mathbf{X}$ & & $\mathbf{X}$ & & $\mathbf{X}$ & $\mathbf{X}$ \\
& $\mathbf{X}$ & & & $\mathbf{X}$ & $\mathbf{X}$ \\
$\mathbf{X}$ & $\mathbf{X}$ & $\mathbf{X}$ & $\mathbf{X}$ & $\mathbf{X}$ & $\mathbf{X}$ \\
& & & & & \\
$\mathbf{X}$ & $\mathbf{X}$ & $\mathbf{X}$ & $\mathbf{X}$ & $\mathbf{X}$ & \\
$\mathbf{X}$ & & $\mathbf{X}$ & $\mathbf{X}$ & $\mathbf{X}$ & $\mathbf{X}$ \\
$\mathbf{X}$ & $\mathbf{X}$ & $\mathbf{X}$ & & $\mathbf{X}$ & \\
$\mathbf{X}$ & & & $\mathbf{X}$ & & $\mathbf{X}$ \\
\hline
\end{tabular}


Appendix 4. Northeast Coastal Long-Term Integrated Science Priorities and Eastern Region Integrated Science Priorities

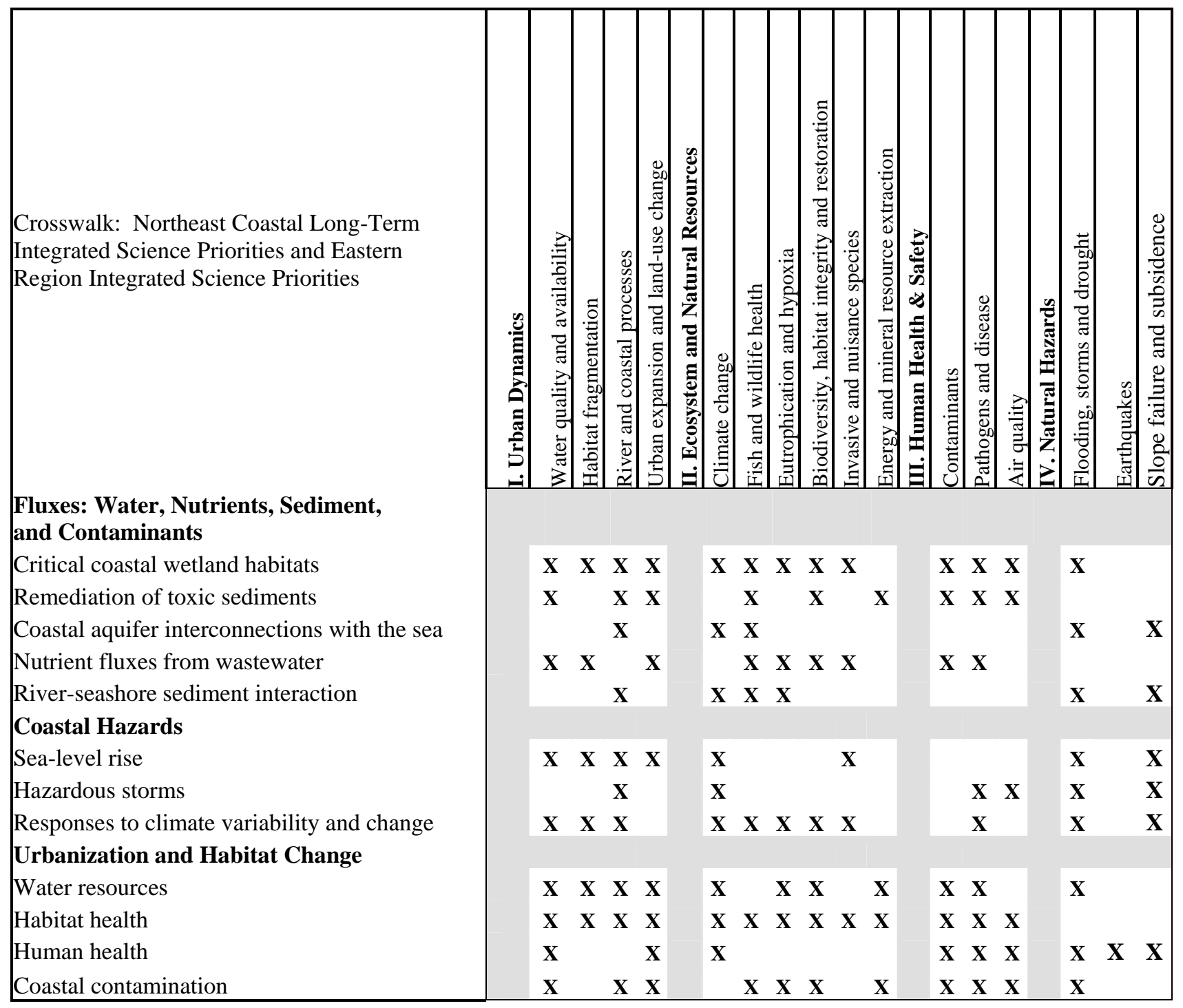


